\title{
Risks and Banking Performance Connection, Risk Management Drivers on the Romanian Banking Sector
}

\author{
Violeta Elena Dragoi \\ violetadragoi@yahoo.com \\ Lucretia Mariana Constantinescu \\ maractinescu@gmail.com \\ Larisa Elena Preda \\ larisapreda@yahoo.com \\ Valahia University of Targoviste, Romania
}

\begin{abstract}
Banking activities occupy a first place in the gross domestic product of each country, by the level of performance achieved through the intermediation activities of the movement of capital and services related to the circulation of monetary assets and the risk strategy. The financial market is extremely fragile due to the influence of a large number of subjective and objective factors. The main purpose of banking activities being to maximize the profit, these activities generate several types of risks, sometimes quite high. To eliminate bank risks, it was necessary to align banks with the provisions of the new Third Basel Accord, which is the key factor for improving banks' financial performance. In 2018, the Romanian banking system consisted of 35 credit institutions, of which seven are branches of foreign banks. All the macroeconomic factors of the Romanian economy - integration, globalization and transactions - provide important chances for the development of the economic and financial performances, the achievement of remarkable profits but also the significant risks. For effective risk management, these must be identified and evaluated, monitored and used tools, techniques, and specific methods of sizing and/or avoiding their negative influence on banking activity.
\end{abstract}

Keywords: liquidity, solvency, risk, performance, Third Basel Accord, banking system

JEL Classification: E42, E43, E51, E52, E 61, F62, G210 .

\section{Introduction}

Banking institutions are financial intermediaries that play a very important role in the financial sector, the functioning of the economic units and the economy in general. Over the years, since the first bank events until now, to create a functional banking system has been a permanent concern that offers a wide range of products and services and meets the requirements of all potential customers.

In the field of banking performance, the research has materialized in a series of valuable judgments that have provided several forms and names, starting with classical school until today, each of which is part of a whole, for deciphering financial performances and their role in the banking activity.

Analysis of the financial condition of a bank is an image of the bank's position at a given moment in the financial-banking environment to which reporting is made, as well as the quality and credibility of the bank in order to establish or continue the business relationships on the different terms.

For the banking company, the profit represents the main source of the capital increase, and its existence or lack thereof has a particular impact on public confidence in the bank. Profit thus contributes to shaping the bank's image on the market. As in any field, the bank profits increase is related to attracting and retaining customers. For this purpose, in order to win the battle on an increasingly competitive market in the coming years, banks will need to bring their bank counter as close as possible to the home or office of the client. Equipped with a welltrained, well-trained clerk or just an electronic terminal that counter should bring as many potential customers as possible, that don't have a consistent relationship with the banks. 
The level of obtained profit by a bank is also a direct consequence of the type of own strategy adopted in the bank's management in the sense of accepting or not the bank risks in the activity it carries out. Although there is a diversification of banks' activity, the interest income still holds most of the bank's total profit.

Interest income originated in loans and all other forms of loans granted by a bank, such as loans with equal rates, over draft account and credit cards.

Taking into account the economic and financial reality both internationally and nationally, Romania as well as other countries is interested in creating a solid banking system that provides an organizational and functional framework according to the expansion of the banking financial mechanisms and processes. In our opinion the appreciation of the financial performance is one of the most important and current strategic objectives of a bank, taking into account the impact of the banking system throughout the economy. We must not forget the fact that a market economy will never operate without profitable and well-organized banks. With the development of the economy and the business environment in our country, the banking system has seen a significant development. However, we always faced with challenges of globalization, being a member of the European Union; Romania has to prove the existence of an efficient banking system, which will face the competition between the countries of the world.

\section{Romanian banking system - brief overviews}

The banking system in Romania was surprised by the economic crisis in a special situation, namely: the pre-accession phase of the EU was just completed and we were full members of European construction after our country became a member of the political-military alliance - NATO, in 2004. These two extremely strong signals for foreign investors contributed to the change of the Romanian economy after 2004, respectively - economic growth ranging from $7.14 \%$ to $16.25 \%$. Foreign direct investment (FDI) also reached record levels, from 5 billion lei in 2004 to 9.5 billion lei in 2008, but in an unsustainable economy like Romania, they took the path of exile through current account deficits equally spectacular starting from 5.1 billion lei in 2004 to 16.8 billion lei in 2008 .

This political and economic conjuncture also had an impact on the banking system, which from 6 branches of foreign banks and 24 banks with majority foreign capital in 2005, reached 10 in 2008, respectively 27, and those with private domestic majority capital, decreasing over the same period from 7 to 3 institutions, given the new competitive conditions created by EU membership (fig. 1).

Figure 1. Evolution of the structure of the Romanian banking system between 2005-2016

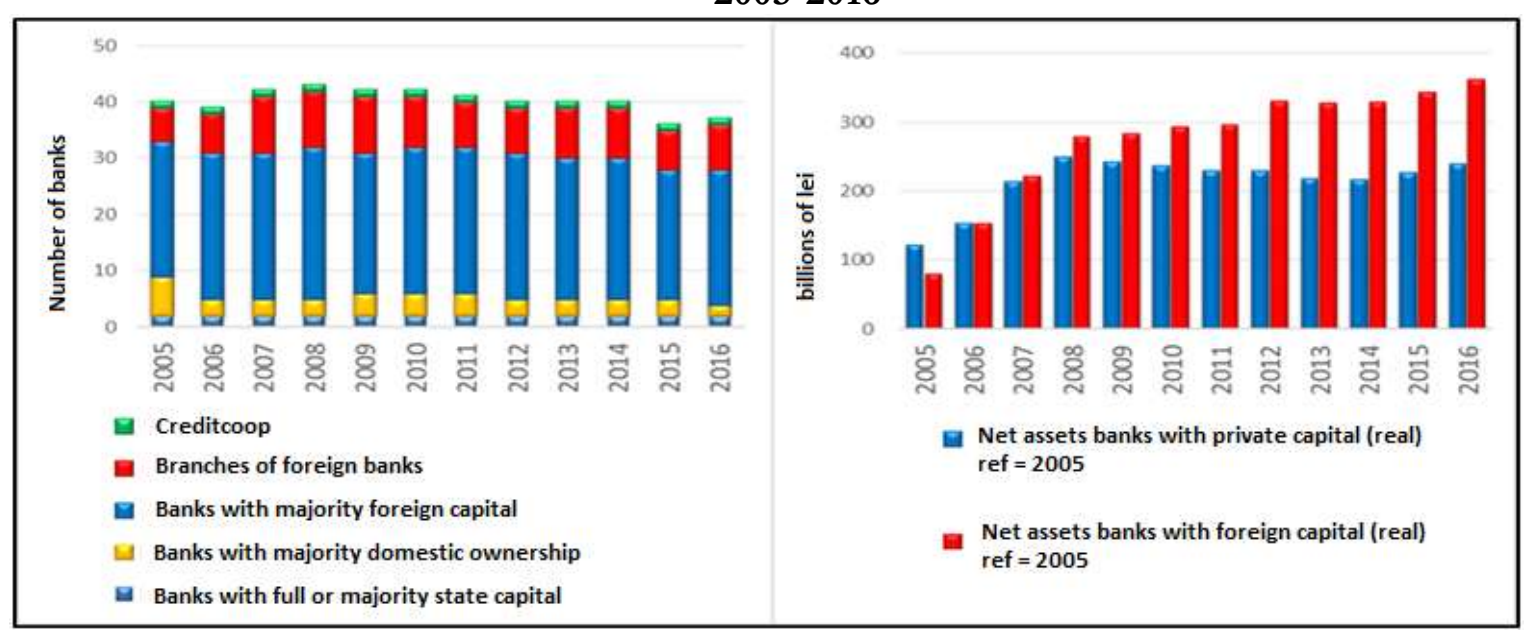

Source: National Bank of Romania Annual Reports available on www.bnr.ro

The new entrants within the Romanian banking system stimulated competition - finally improving the quality and efficiency of the services - given that these institutions benefited from the extremely strong support of the parent banks and the net assets (in real terms) of the banks 
with foreign capital increased from 80 to 277 billion RON during the 2005-2008years (increasing approximately $246 \%$ ).

Taking into account the fact that the number of banks with majority state capital remained constant at the level of only two banks (CEC Bank and EximBank) - thus having no capacity for influence - the same trend had also the net assets (in terms real) of banks with private capital, respectively an increase from 121 to 247 billion lei (increase of about 104\%). The growth of the aggregate net assets of the banks with private capital at a much lower pace compared to those with foreign capital is due to the decrease of the number of the private banks with Romanian capital but also their weaker capacity compared to the institutions supported from abroad by parent banks, as can be seen after 2009, when the two aggregate indicators had opposite trends and the differences became significant (fig.1).

After 2009, the structure did not suffer major changes, the variations being very small, in a declining trend, with the largest difference recorded in 2015 , respectively by two banks with foreign capital and two branches of foreign banks, so that the total number of institutions (including the Creditcoop network) was reduced by 10\% from 2005, to 36 units. The changes were as follows: Transilvania Bank merged through absorption with Volksbank, as in the case of OTP Bank and Millennium Bank, and the branches of Montepio Credito-Instituicao Financeira de Credito Portugal and The Royal Bank of Scotland have ceased their activity on the territory of our country.

At the end of 2017, the Romanian banking sector comprised 35 credit institutions (www.bnr.ro): two banks with full or majority capital owned by the Romanian, four credit institutions with majority Romanian private capital, 22 banks with majority foreign capital and seven branches of foreign banks. About $77 \%$ of the banking sector's assets in Romania are held by institutions with foreign capital in 2017, downward trend from $91.3 \%$ at the end of 2016. At the end of 2017, the banks with Austrian capital held a market share of 25\%, followed by French and Dutch banks (market share of 13.5\% each), those with Italian capital (10\%) and with Greek capital $(9 \%)$.

\section{Banking performance}

Banking performance is the level at which a bank's financial stability is measured, a level characterized by the low risks and a normal evolution of profits over the period under review. The efficiency of the Romanian banking system can be analysed both from microeconomic and macroeconomic point of view.

There cannot be evaluated effectively the banking risks when there is no adequate information system, but this difficulty is currently overcome. Depending on the bank's own information, it can be obtained a radiograph of performance or non-performance, the gains and risks must be simultaneously balanced as can be seen in the Du Pont analysis system.

Figure 2. Du Pont scheme

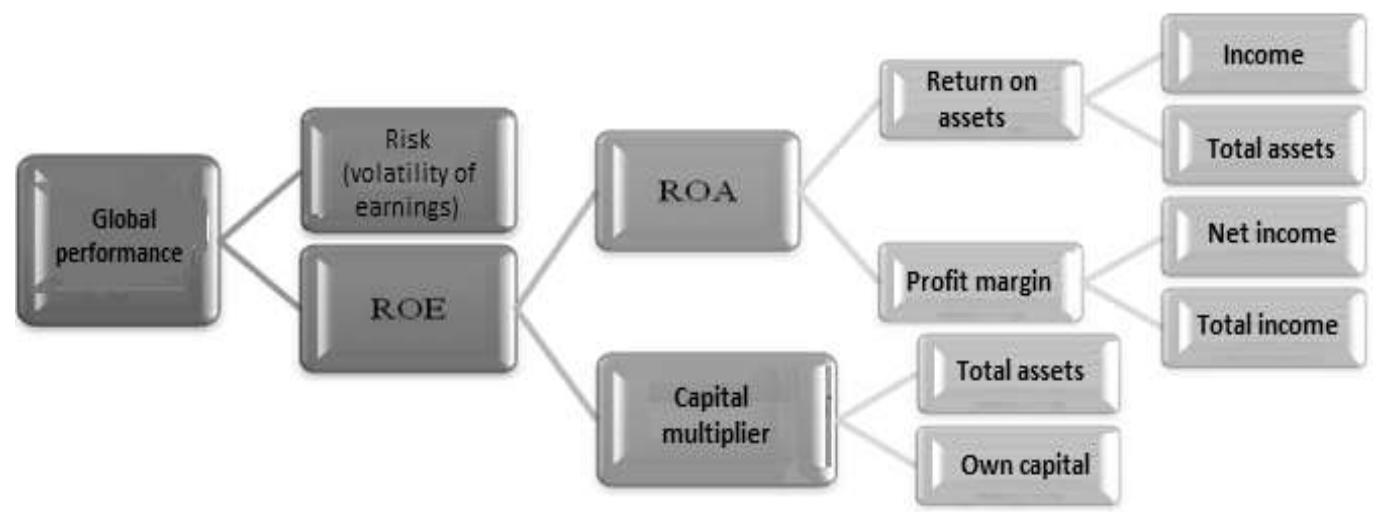

Source: Badea, L. (coord.), Socol, A., Dragoi, V., Driga, I. (2010), p. 374. 
The main indicators for assessing a credit institution's performance are Return on Assets (ROA) and Return on Equity (ROE). The return on assets (ROA) expresses the profitability of the assets or the number of assets rotation (uses) achieved the net profit. It is determined as the ratio between the net profit and the total assets of the banks. Return on equity (ROE) informs the bank's management of the amount that was earned on the unit of the accounting value of the shareholders' investment in the bank (Badea, 2010).

It is determined as a ratio between net profit and the equity and provides information on: profit generation rate, operational efficiency, financial indebtedness, or tax liability forecast. In order to assess the viability of the Romanian banking system we analysed and evaluated the rate of economic and financial profitability in the Romanian banking system.

Regarding the financial performance of the Romanian banking system, they reveal very clearly that the financial results of the Romanian banks were affected by: the economic crisis, starting with 2009, by the measures imposed to strengthen the resilience of the banking sector, by reducing the credit risk through covering non-performing loans with provisions and by reducing the interest rates and changing the calculation method by converting IFRSs from 2012. Thus, the years preceding the crisis were dominated by more than satisfactory financial results, respectively an aggregate net profit level of 2 - 3.40 billion lei - the peak being registered in 2008 - one year in a global financial crisis - which means a pro-cyclical attitude, lacking prudential measures - and even though banking institutions were aware of the sensitive context of the situation, continued lending to individuals or firms that were less well informed or misinformed, and the results could be seen in the increase in the rate of non-performance in the period that followed.

The 2009 year was dominated by a decrease in the level of lending due to banks' more reticent and selective attitudes - given by the macroeconomic context, more difficult access to funding sources, but also a deterioration of the employment situation and the exchange rate. However, the year was concluded with positive results: ROA $-0.25 \%$, ROE $-2.89 \%$, and the aggregate net profit was 680 million lei, after a reorganization of the banking institutions that renounced at 128 of units and 3,724 employees respectively, and an increase in provisions from 7.6 to 15 billion lei.

Since the following year the situation has changed radically and this has also been attributed to the Romanian Government Emergency Ordinance no. 50/2010 regarding a banking commission reduction or even interest - according to a UE Competition Council Report in 2011, strictly from the elimination of the early repayment commission, which facilitated refinancing and the customer mobility, generating consumer savings of approximately 290 million euro, respectively 1.23 billion lei.

These measures were accompanied by an increase in the volume of provisioning - up to 23.6 billion lei, in the context of even more severe deterioration in the quality of the loan portfolio. Although unit closures and redundancies continued: 255 units/1,145 employees - in 2010, 124/981 in 2011, 323/4003 in 2012, the financial results were negative, reaching a minimum in 2014, when an ample process started of clearing the bank balance sheets of bad loans, which also represented the starting point for a sustainable recovery of credit, a correct view of the situation and, implicitly, better provisioning, which led, after 2014, to: ROA - $(-1.32) \%$, ROE - (-12.45)\%, aggregate net profit - (-4.67) billion lei, followed by a 2015 characterized by a big plus sign ROA $-1.24 \%$, ROE - $11.77 \%$ and the net profit went up to 4.47 billion lei and a significantly lower 2016 (fig.3). 
Figure 3. Evolution of net aggregated profit, ROA, ROE during 2005-2016 years

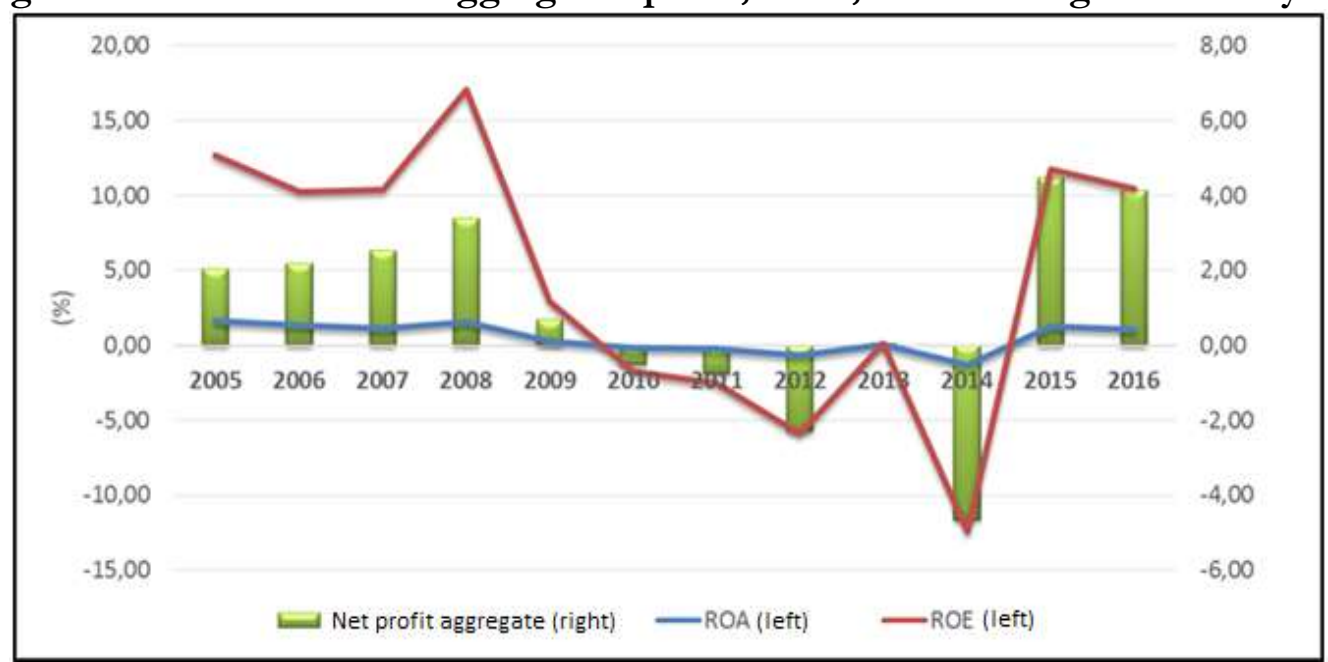

Source: Annual Reports of the National Bank of Romania available on bttps:/ / www.arb.ro/ sistemul-bancar-din-romania/ sistemul-bancar-din-romanial

Subsequently, the evolution of the two profitability indicators has improved due to the favourable macroeconomic environment and the low level of the financing costs. Thus, in June 2018, ROE stood at $15.71 \%$ compared to $12.91 \%$ in June 2017 , and ROA increased to $1.66 \%$ in June 2018 (fig. 4).

Figure 4. Performance Indicators (ROE, ROA)

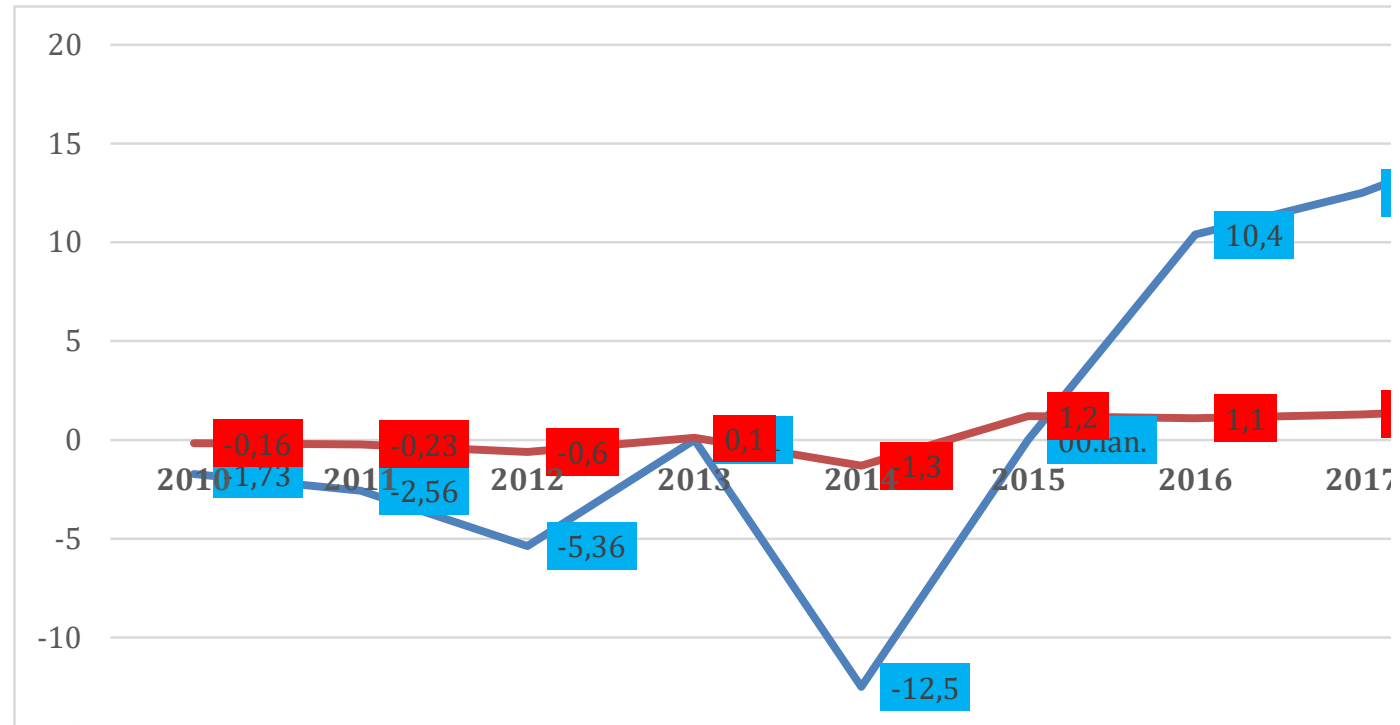

Source: bttps:// wwm.bnr.ro/Regular-publications-2504.aspx

The positive performance in the profitability area was also accompanied by the acceleration of lending, even if the level of financial intermediation in Romania is the lowest among the states in the European Union (26.4\%), decreasing from 40\% in 2011 (fig. 5). 
Figure 5. Evolution of the financial intermediation of Romania and the European Union (EU) average between 2008 - 2016 years and the situation of EU member states in 2016

$(\%)$

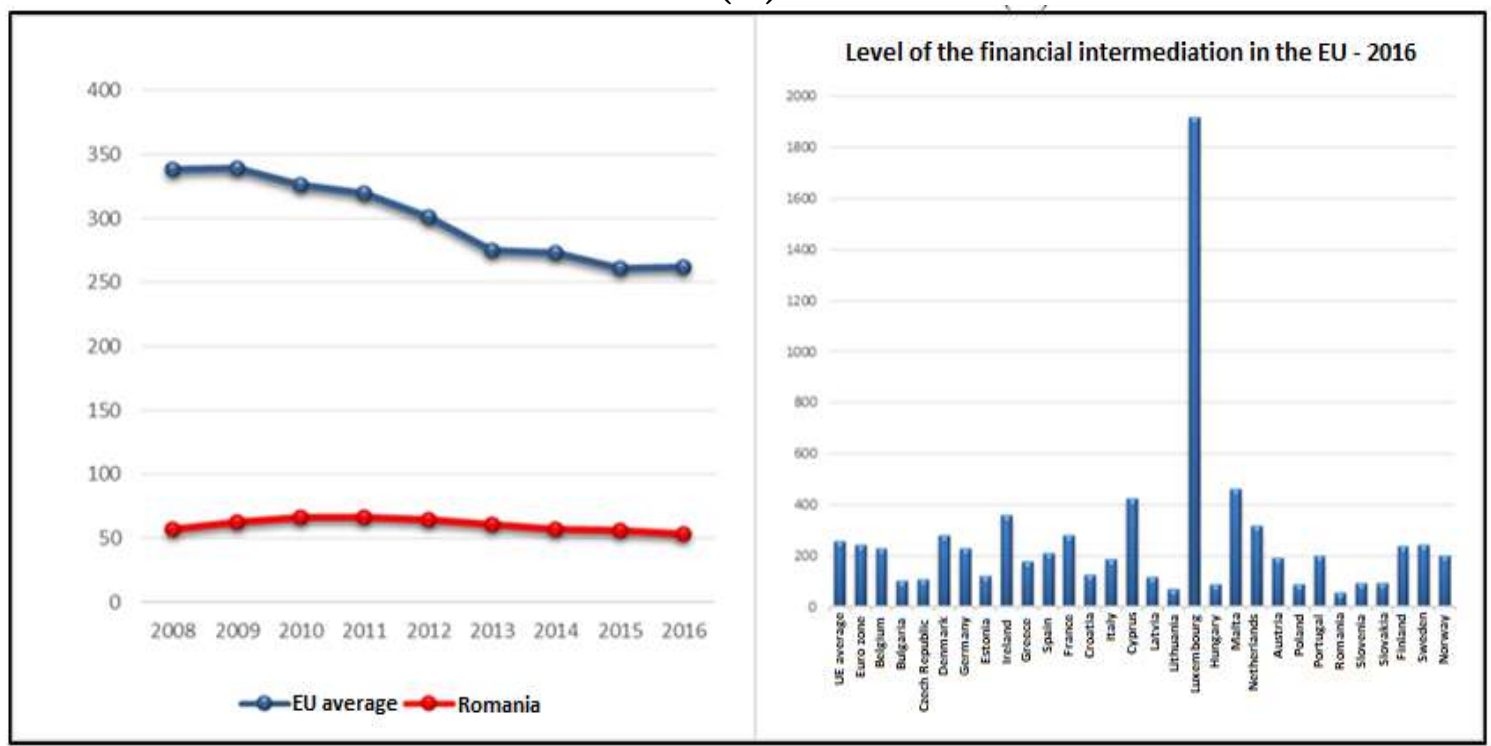

Source: Eurostat and National Bank $f$ Romania

In addition to reimbursements, the rapid GDP growth influenced the financial disintermediation process, on the one hand, and by clearing the balance sheets of nonperforming credit, on the other hand. The share of banking assets in GDP is $50 \%$. By comparison, the share of banking sector assets in GDP is 255\% and 288\% in the euro area.

The distribution of the financial sector assets in Romania show that credit institutions have a share of $75.3 \%$.

\section{Banking risk}

Banks should delimit an independent risk management function with sufficient authoriy, status, independence, resources and access to the board of directors. Risks must continuously identified and monitored both at entity level and at individual level, and the sophistication of the bank risk management and internal control infrastructures should keep up with any changes to the risk profile of the banks (including growth) as well as the external factors generating risk. Effective risk management requires an open and timely internal communication both at the bank level and through reporting to the board and senior management of the bank.

In order to maximize the profit, the credit institutions always faced with all sorts of risks, knowing that banking risk based on the principles of banking, which states that maximizing profits involves exposure to the high risk.

Risk management, these must be identified and evaluated, monitored and used tools, techniques, and specific methods of sizing and/or avoiding their negative influence on the banking activity. Banking risk is an important component of both bank management and a bank's strategy, aiming to maximize its profit, while maintaining risk to an acceptable level.

Assume the risk from the banks involves (Badea and all, 2010):

$>$ compliance with the prudential rules imposed by the national regulatory authority;

$>$ balancing between the size of the profit and opening the bank to risk;

$>$ accepting losses under the conditions of unaffected the financial statements, which may covered by profit or provisioning.

The risk must dimensioned so that the loss produced by its materialization can considered as normal for the activity of the bank so as not to damage the image of the bank.

The risk-profit relationship becomes essential in the taking of banking decisions, highlighting three types of banking management (Dragoi, 2013): 
$>$ aggressive management, characterized by maximizing the profits through market penetration policies and eliminating competition, under the conditions of high risk;

$>$ moderate management, characterized by the maintenance of the level of profit through policies aimed at maintaining the bank's position on the market in the conditions of avoiding risky commitments;

$>$ Prudent management, focusing on the risk minimization through policies aimed at eliminating losses, reducing costs and restrictive refinance strategy.

The banking risk management aims: minimizing expenses, losses; changing the behaviour of the banking officials and also changing the public image of the bank.

The most important risks involved into the banking activity are the financial risk, delivery risk and environmental risk. The financial risk resulting from any banking transaction that is subject to a potential risk.

The most important financial risks are as follows: credit risk; interest rate risk; liquidity risk; currency risk an insolvency risk (Badea and all, 2013).

Credit risk is the risk that occurs when a bank customer, a party to the contract, fails to fulfil its obligations under the terms and conditions of the contract. Such losses may be the result of the bankruptcy, a temporary change in the market conditions, or other factors that may affect the ability to pay the loan. Credit risk consists of risk of the debtor's insolvency, which may result a loss of the borrowed amount and risk of immobilisation if the debtor fails to meet the payment commitment on maturity.

Interest rate risk refers to the financial losses caused by interest rate fluctuations, which affects both the client's profits and the state of indebtedness to the bank. A major increase in the interest rate can create a financial pressure on the client's activity that will not be able to pay the amounts due.

Liquidity risk occurs when the bank cannot pay its due payment obligations. The risk is due to inconsistency between assets and liabilities in the cash flow. The art of effectively managing a bank is to know how to handle liquidity to deal with the massive and unexpected withdrawals of its creditors.

Currency risk closely related to interest rate risk and liquidity risk. It appears due to the inconsistency between: currency, active and passive. The currency may fluctuate in an unexpected or higher direction than expected. This type of risk determined by the foreign exchange transaction that affects exports or those receipts from exports do not cover the contracted debt. The main factors leading to the increase of foreign exchange risk are the exchange rate volatility, open foreign exchange position, etc. The methods of avoiding the foreign exchange risk developed on the derivatives market by using hedging instruments (neutralization, risk compensation).

Insolvency risk is the consequence of one or more of the risks presented and which the bank has not prevented. The insolvency risk shows how much of the bank's own funds may fall before the creditors' position is endangered.

The European regulatory constraints on lending, the inclination to save, the reluctance to contract new loans amid the lack of confidence in the evolution of the economy that has crossed the crisis and the restructuring of banks' portfolios have determined that the loan/deposit ratio in the banking system to become subunit.

According to the new regulations, the liquidity ratio was maintained in the range 1.4-1.6 for 6 years, and after 2015 it is around 1.9-2, amid a recovery of the banking system, for the achievement of effects on the strategy launched in 2009 to attract deposits which from a loan granted/attracted deposits ratio of $122.03 \%$ in 2008, progressively reached up to $74.74 \%$ in 2017 (Chart no. 4), due to a growth in net deposits higher than that of credit growth (for example in 2009: +9.7 respectively +1.4 ). 
Figure 6. Evolution of the credit risk and loan/deposit ratio (\%)

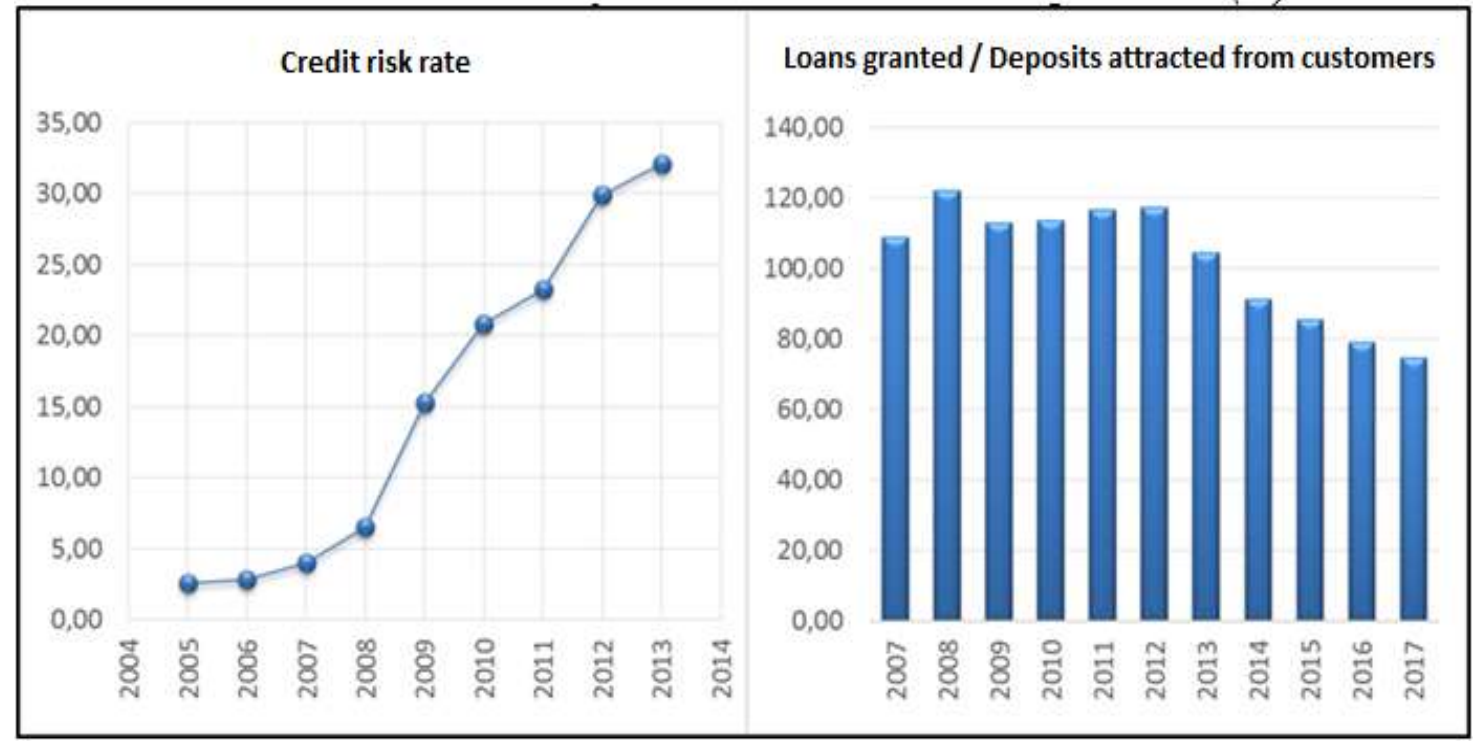

Source: National Bank Of Romania Annual Reports available on www.bnr.ro

This strategy was forced by a reduction in funding from parent banks (external liabilities declined from $26.8 \%$ - in 2010 to $11.7 \%$ - in 2016), which due to excessive credit risk (calculated as the weighted average of the individual bank risks, in terms of credit volume and bank exposure) - registered especially after 2009, forced them to more efficient management of financing sources, attracting deposits representing the stated desideratum - leading to a reduction volatility in attracted resources - which has happened: the deposits attracted from firms and the population have increased from a total of $46 \%$ - in 2010, to $63.9 \%$ - in 2016 . This was a justified action, since the credit risk started after 2008 steep on an ascending slope from 6.52 to 16.29 in 2009 and to 32.14 in 2013 (fig. 6).

\section{The Third Basel Accord}

In order to quantify and monitor the banking risks, it was necessary to align banks with the provisions of the new Third Basel Accord, which ensures the existence of an efficient management system of the information in banks, being the key factor for improving the financial performance of the banks that own it.

The purpose of the Third Basel Accord is to strengthen the stability of the banking system by redressing the shortcomings highlighted by the current crisis. The Third Basel Capital Accord improves the quality of the capital base through extensive quantitative and qualitative requirements, new liquidity management requirements, a counterparty credit risk review, and a benchmark for banks in the Basel Committee member countries. These new standards designed to strengthen banks' ability to absorb shocks, avoiding the use of public funds for recapitalization, beneficial effects also directed to investors, consumers or governments.

Applying the Third Basel rules to reduce the frequency of financial crises through prudential measures will fundamentally affect the profitability of the banking industry.

The reforms address macro-prudential measures on the own funds levels, sectoral risk weights, stricter liquidity requirements, stricter requirements for large exposures, more conservative transparency requirements.

These measures are designed to improve the ability of the banking sector to absorb shocks through the superior management of the risk, enhanced governance and increased transparency conditions. In Romania, the Third Basel standards governing the access to activity, supervision and prudential rules applicable to the credit institutions and the investment firms were planned to be implemented gradually from 1 January 2014 to the end of 2018. 
The gradual adaptation to the capital requirements does not highlight, as a first step, problems in capitalization requirements at the level of the Romanian banking system.

From 2014 until now, the NBR together with the Romanian Banking Association is conducting an exercise on the application of the CRD IV requirements on capital and liquidity, which aims:

o determining the effective impact of CRD IV

o identify the operational problems

o Substantiating the decisions of the regulatory authorities on the strategy during the transition period.

Thus, the Third Basel package, as a whole, regulates banking activity from the following perspectives:

- Risk weights involved in the banking activity;

- Capital and liquidity standards imposed on the credit institutions;

- New requirements on the corporate governance;

- Framework for the use of credit ratings

- Minimum administrative penalties

- Collaboration and exchange of information between national supervisory authorities.

Under the Third Basel regulations, banks will implement the Liquidity Coverage Ratio (LCR) gradually, from 2015 to 2019 and they will be required to set up a reserve equal to $7 \%$ of the value of their loans compared to $2 \%$ as it stipulated in the Second Basel Accord, and the equity ratio will have to reach $8 \%$ by the end of 2018 (Table 1).

Table 1

Transition to BASEL III / CRD IV

\begin{tabular}{|c|c|c|c|c|c|c|}
\hline & 2014 & 2015 & 2016 & 2017 & 2018 & 2019 \\
\hline $\begin{array}{l}\text { Minimum } \\
\text { requirement for basic } \\
\text { level } 1 \text { own funds }\end{array}$ & $4.00 \%$ & $4.50 \%$ & $4.50 \%$ & $4.50 \%$ & $4.50 \%$ & $4.50 \%$ \\
\hline $\begin{array}{l}\text { Capital conservation } \\
\text { buffers (basic level } 1 \\
\text { own funds) }\end{array}$ & & & $0.625 \%$ & $1.25 \%$ & $1.875 \%$ & $2.50 \%$ \\
\hline $\begin{array}{l}\text { Minimum basic level } \\
1 \text { own funds } \\
\text { requirement }+ \text { Capital } \\
\text { conservation buffers }\end{array}$ & $4 \%$ & $4.50 \%$ & $5.125 \%$ & $5.75 \%$ & $6.375 \%$ & $7 \%$ \\
\hline $\begin{array}{l}\text { Countercyclical capital } \\
\text { buffer }\end{array}$ & & & $\begin{array}{l}<=0.625 \\
\%\end{array}$ & $\begin{array}{l}<=1.25 \\
\%\end{array}$ & $\begin{array}{l}<=1.875 \\
\%\end{array}$ & $<=2.5 \%$ \\
\hline $\begin{array}{l}\text { Removing the } \\
\text { national deductions }\end{array}$ & $20 \%$ & $40 \%$ & $60 \%$ & $80 \%$ & $100 \%$ & $100 \%$ \\
\hline $\begin{array}{l}\text { Minimum } \\
\text { requirement for level } \\
1 \text { own funds }\end{array}$ & $5.50 \%$ & $6 \%$ & $6 \%$ & $6 \%$ & $6 \%$ & $6 \%$ \\
\hline $\begin{array}{l}\text { Minimum capital } \\
\text { requirement }\end{array}$ & $8 \%$ & $8 \%$ & $8 \%$ & $8 \%$ & $8 \%$ & $8 \%$ \\
\hline $\begin{array}{l}\text { Minimum capital } \\
\text { requirement }+ \text { Capital } \\
\text { conservation buffers }\end{array}$ & $8 \%$ & $8 \%$ & $8.625 \%$ & $9.125 \%$ & $9.875 \%$ & $10.50 \%$ \\
\hline GSII buffer & & & $25 \%$ GSII & $50 \%$ GSII & $75 \%$ GSII & $\begin{array}{l}100 \% \\
\text { GSII }\end{array}$ \\
\hline OSII buffer (optional) & & & MAX.2\% & & & \\
\hline
\end{tabular}


International Conference "Risk in Contemporary Economy" ISSN-L 2067-0532 ISSN online 2344-5386

$\mathrm{XX}^{\text {th }}$ Edition, 2019, Galati, Romania,

"Dunarea de Jos" University of Galati, Romania - Faculty of Economics and Business Administration

\begin{tabular}{|l|r|r|r|r|r|r|}
\hline & $\mathbf{2 0 1 4}$ & $\mathbf{2 0 1 5}$ & $\mathbf{2 0 1 6}$ & $\mathbf{2 0 1 7}$ & $\mathbf{2 0 1 8}$ & $\mathbf{2 0 1 9}$ \\
\hline $\begin{array}{l}\text { Systemic risk buffer } \\
\text { (optional) }\end{array}$ & & & \multicolumn{2}{|c|}{$1 \%-3 \%(5 \%$ or more) } & \\
\hline $\begin{array}{l}\text { Liquidity Coverage } \\
\text { Ratio (LCR) }\end{array}$ & Obs. & $60 \%$ & $70 \%$ & $80 \%$ & $90 \% / 100 \%$ & $100 \%$ \\
\hline $\begin{array}{l}\text { Net Stable Financing } \\
\text { Indicator (NSFR) }\end{array}$ & & & & & \\
\hline $\begin{array}{l}\text { OBS: The GSII level varies between (1\% and 3.5\%), depending on the systemic importance class at the overall } \\
\text { level of the institution }\end{array}$
\end{tabular}

Source: The National Bank of Romania available on www.bnr.ro

In Romania (fig.7) according to the Bank's current prudential regulations, according to the NBR, during the implementation of the additional capital requirements of Basel III (20142017), the solvency ratio remained at a high level of $19.1 \%$ inJune 2016, provided that the minimum threshold established under the European CRD IV / CRR regulatory framework is $8 \%$, as a result of the central bank's proactive use of the regulatory instruments and prudential supervision.

Figure 7. Evolution of the capital adequacy indicators (percentages)

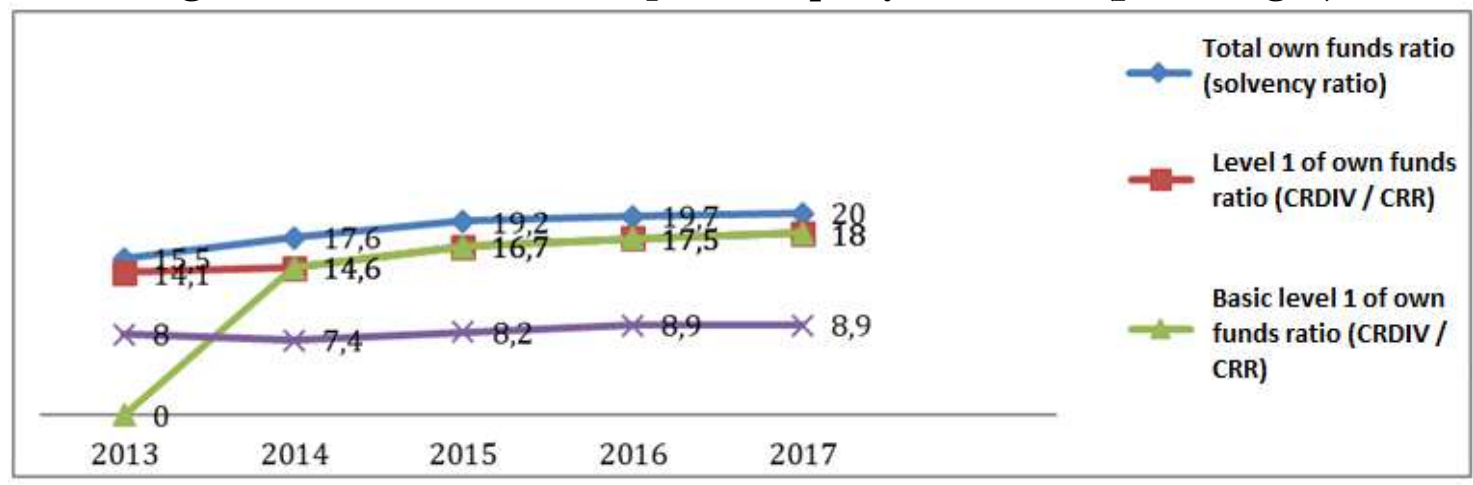

Source: The National Bank of Romania

\section{Conclusions}

The banking system has been significantly achieved by the new rules of the Third Basel Accord and the amendments to the Fiscal Code. Increasing the restrictiveness of credit standards is not in itself an element of concern for competition in the banking sector, but its corroboration with a high level of customer indebtedness leads to a reduction in customer mobility.

As it is known, an increased level of customer mobility is the effect of a normal competitive environment and the aim of competition law is precisely to maintain and stimulate competition and a normal competitive environment to promote the consumer interests.

It is very important that banks' performance improves, thus contributing to their capitalization and, implicitly, to increase the credit appetite, especially nowadays when the banking system brings major changes in the business environment.

Some of the banks in the industrialized world enter into underwriting of securities, insurance companies, portfolio management and investment. The result of these changes is that banks have become stronger in the global business world. 
International Conference "Risk in Contemporary Economy" ISSN-L 2067-0532 ISSN online 2344-5386

$X^{\text {th }}$ Edition, 2019, Galati, Romania,

"Dunarea de Jos" University of Galati, Romania - Faculty of Economics and Business Administration

\section{References}

1. Badea, L. (coordinator), Socol, A., Drăgoi, V., Drigă, I.(2010), Managementul riscului bancar, Economica Publishing House, Bucharest, 2010.

2. Badea, L., Neculaesu, S., Socol, A., Mocanu, F. (2013), Operational Risk. Mode of Administration on in the banking system in Romania, WSEAS Proceedings of the Conference on Risk Management, Assessment And Mitigation (RIMA'13), pp. 485490 available on http://wnw.wseas.us/elibrary/conferences/2010/Bucharest/RIMA/RIMA-87.pdf.

3. Dragoi, V. E. (2013), Gestiune bancară, V alabia University Press Publishing, Targoviste.

4. www.bnro.ro 